\title{
PERSONAL BRANDING DALAM MEDIA SOSIAL: STUDI PADA MAHASISWA PENGUNJUNG MUSEUM MACAN
}

\author{
Davi Ravindra Aziz
}

Universitas Indonesia, Depok, Indonesia

\section{Article Information}

Received: 7 Oct. 2019

Accepted: 11 Mar. 2020

Published: 18 May 2020

DOI: $10.33555 /$ ijembm.v7i1.107

Corresponding Author:

Davi Ravindra Aziz

Depok, Indonesia

daviaziz27@gmail.com

ISSN $\quad 2338-8854$

eISSN 2620-9918

\begin{abstract}
The technology of internet is keep developing which led to a variety of social media which is currently often used by teenagers, especially college students. Social media has become a new platform for college tudents to do personal branding activities, especially in Instagram. The aim of this research was to find out the process of personal branding in the social media conducted by visitors in Museum MACAN. The concepts of this research are social media, personal branding, and youth. Data collection and information obtained through in-depth interviews with two informants who fit the criteria. The results of this study was that the two informants had their own way of building their personal branding and this affects them on maintain their accounts such as pay attention on likes given, numbers of followers, and other accounts they are followed. The second reason for this informant to visit the Museum MACAN was based on the same thing which they want to follow the trend.
\end{abstract}

Keywords : Teenagers, Museum, Personal Branding, Instagram, Trend

\begin{abstract}
ABSTRAK
Teknologi internet yang semakin berkembang memunculkan berbagai media sosial yang saat ini kerap digunakan oleh remaja, khususnya mahasiswa. Media sosial telah menjadi sebuah platform baru bagi mahasiswa dalam melakukan kegiatan personal branding, khususnya Instagram. Tujuan penelitian ini adalah untuk mengetahui proses pembentukan personal brandingdi media sosial yang dilakukan pada pengunjung Museum MACAN. Konsep pada penelitian ini yaitu media sosial, personal branding, dan remaja. Pengumpulan data dan informasi diperoleh melalui wawancara mendalam dengan dua informan yang sesuai dengan kriteria. Hasil dari penelitian ini ditemukan bahwa kedua informan memiliki cara sendiri dalam membangun personal branding mereka, dan hal ini mempengaruhi mereka dalam menjaga akun mereka seperti memperhatikan likes yang diberikan, jumlah pengikut, serta akun-akun yang diikuti. Alasan kedua informan ini mengunjungi Museum MACAN didasari oleh hal yang sama, karena mereka memiliki keinginan untuk mengikuti tren yang ada.
\end{abstract}

Keywords: Remaja, Museum, Personal Branding, Instagram, Tren 


\section{Pendahuluan}

\subsection{Latar Belakang}

Perkembangan teknologi internet telah mendorong munculnya berbagai media sosial yang sangat dekat dengan kehidupan manusia. Beberapa media sosial seperti Facebook, Twitter, dan Instagram menjadi pilihan utama bagi para pengguna teknologi digital sekarang ini. Di Indonesia sendiri, media sosial pun sudah menjadi bagian kehidupan yang tak terpisahkan dalam keseharian masyarakat. Riset yang dilakukan oleh APJII menunjukkan bahwa media sosial Facebook dan Instagram menjadi dua media sosial yang paling sering digunakan oleh masyarakat Indonesia, khususnya bagi mahasiswa. Instagram menjadi media sosial yang paling sering dipakai untuk bersosialisasi secara online dalam bentuk unggahan foto dan video. Saat ini Instagram digunakan mahasiswa untuk membentuk personal branding atau ajang aktualisasi diri. Penggunaan media sosial ini mempermudah penggunanya untuk mengubah dan mempertahankan persepsi orang lain terhadap dirinya melalui foto yang diunggah.

Personal branding dapat diartikan sebagai pembangunan merek diri seseorang. Dulu orang pada umumnya melakukan personal branding secara offline dengan cara membangun persona dirinya melalui pakaian yang dikenakan, perilaku sehari-harinya, cara berbicara, dan sebagainya. Dengan kemunculan media sosial, membangun personal branding secara offline menjadi berbeda jika diterapkan ke dalam dunia online. Personal branding dalam dunia online lebih menekankan pada bagaimana orang menampilkan foto dalam akun media sosial mereka, penampilan mereka dalam foto, gaya berpakaian, tempat yang dikunjungi, objek apa yang mereka berusaha tunjukan, serta konsistensi pengaturan foto dalam akun. Personal branding dilakukan mahasiswa untuk membentuk keseluruhan potensi, kualitas, dan nilai-nilai yang berada dalam diri mereka.

Harga diri adalah salah satu konseptualisasi positif dan negatif dan evaluasi diri terkait persetujuan atau ketidaksetujuan diri seseorang. Dengan demikian, mencari tanggapan dari orang lain melalui media sosial mungkin akan menjadi indikasi yang jelas tentang harga diri seseorang. Dapat dibayangkan bahwa media sosial dapat meningkatkan harga diri, karena individu memiliki kemampuan memilih bagaimana mereka ingin menampilkan diri mereka sendiri dan karena mereka dapat menerima dukungan sosial atau umpan balik sosial positif yang tidak diperoleh di tempat lain. Di sisi lain, media sosial dapat menumbuhkan rasa harga diri yang rendah melalui kesempatan untuk membandingkan dengan orang lain dan kemungkinan bahwa seseorang dapat menerima umpan balik sosial yang negative atau tidak sama sekali. Aerni (2014) menemukan bahwa foto-foto yang dianggap 'cantik' menghasilkan likes paling banyak, dan likes ini, menurut Wendt (2014), bertindak sebagai pujian, memberikan validasi pribadi dan "hadiah" keindahan untuk pengguna (hal.27). Khusus untuk memposting gambar di media sosial, Tazghini dan Siedlecki (2013) melaporkan bahwa individu dengan rasa harga diri yang lebih rendah lebih mungkin untuk berbagi foto di media sosial daripada mereka yang memiliki rasa harga diri lebih tinggi. Sebaliknya, harga diri rendah juga telah dikaitkan dengan lebih banyak tampilan promosi diri di gambar profil media sosial (Mehdizadeh, 2010). Kemampuan untuk mengedit dan memilih selfie mana yang diposting, adalah gambaran diri ideal dan menguntungkan diri sendiri (Gonzales \& Hancock, 2011; Toma, 2013) yang dapat meningkatkan persepsi diri secara keseluruhan. Menurut gagasan Goffman (1956), memposting foto secara online dapat diartikan sebagai front stage acting. Ini dapat dikaitkan dengan manajemen kesan, di mana seseorang secara selektif mengubah penampilan. Selain itu, menerapkan metafora topeng, penyembunyian karakteristik tertentu sambil menekankan aspek yang berkontribusi dalam membentuk diri yang ideal dan menggambarkan diri secara indah di media sosial. 
Bentuk aktualisasi diri setiap orang berbedabeda, salah satunya ditampilkan melalui perilaku narsisme agar mereka mendapatkan pengakuan serta pengaguman dari lingkungannya. Mereka berusaha untuk berpenampilan semenarik mungkin untuk mendapatkan pengakuan serta daya tarik. Selain berpenampilan menarik, mereka harus menyesuaikan latar tempat agar cocok dan sesuai dengan penampilan yang mereka sendiri. Hal ini mendorong terjadi banyaknya remaja, khususnya mahasiswa, yang mengunjungi berbagai tempat umum yang sedang ramai dikunjungi orang dan mengunggah foto dirinya di media sosial mereka terutama Instagram. Salah satu tempat umum yang sedang sering dikunjungi oleh remaja sebagai sarana aktualisasi diri mereka adalah museum.

Museum kini tidak lagi menjadi tempat atau bangunan yang menyimpan dan mengoleksi barang-barang bersejarah saja. Seiring dengan perkembangan zaman, mulai muncul jenis museum baru yang khusus menyajikan karyakarya seni. Beberapa di antaranya adalah Museum Louvre di Perancis dan Museum of Modern Art (MoMA) di New York, Amerika Serikat. Museum seni ini berhasil menarik banyak perhatian dari masyarakat. Di Indonesia sendiri, museum seni semakin berkembang dengan dibukanya Museum Art 1 dan Museum MACAN. Hadirnya art museum ini telah berhasil menarik banyak perhatian dari masyarakat, salah satunya adalah kalangan mahasiswa, terhitung dari banyaknya jumlah pengunjung yang berasal dari kalangan mahasiswa yang datang ke museum ini. Motivasi pengunjung yang datang ke museum saat ini telah berubah seiring dengan munculnya art museum ini. Sebelumnya, pengunjung yang datang ke museum memang memiliki niat untuk meneliti, mempelajari, atau menikmati setiap karya seni yang ada, saat ini, banyak pengunjung yang berniat datang ke museum karena tertarik dengan karya seni yang ditampilkan. Mengunjungi art museum juga menjadi salah satu cara pengunjung yang mayoritas berasal dari kalangan mahasiswa untuk membangun personal branding mereka.

\subsection{Permasalahan Penelitian}

Saat ini, definisi museum sudah mengalami pergeseran. Museum tidak lagi sepenuhnya dapat dikatakan sebagai lembaga non-profit karena sudah berorientasi pada tujuan komersil. Dulu, museum di Indonesia pada umumnya hanya bertujuan untuk menunjukkan hasil karya dan memberikan ilmu pada masyarakat, sehingga tidak berusaha untuk menyajikan sesuatu yang menarik. Perubahan ini membuat peran museum berkembang menjadi tempat preservasi, penelitian dan komunikasi, yang tujuannya untuk menyampaikan misi edukasi sekaligus rekreasi kepada masyarakat. Hal ini mengakibatkan jumlah pengunjung yang tertarik untuk datang relatif sedikit dimana museum sejarah hanya menarik pengunjung dengan minat terhadap sejarah saja. Berbeda dengan saat ini, museum sudah tidak lagi hanya berbasis pada objek atau koleksinya, melainkan pada publik. Museum berperan menyediakan pekerjaan, menarik turis, menghasilkan aktivitas di banyak sektor, berkontribusi bagi regenerasi perkotaan, dan mendukung pertumbuhan industri kreatif dan persaingan kota (Carvalho et al., 2014). Oleh karena itu, beberapa waktu belakangan ini mulai muncul kategori museum baru yang diperuntukkan untuk mempertunjukkan karya seni yang menarik, khususnya karya seni rupa (art museum). Kategori museum seni ini mulai bermunculan di negara-negara Barat, khususnya Eropa dan dilanjutkan oleh Amerika, dan kini Asia.

Menurut survey oleh Culture Track di Amerika Serikat pada tahun 2017, 37 persen dari responden survey tidak melihat museum seni sebagai sebuah pengalaman budaya. Sementara $81 \%$ responden terlibat dalam pengalaman budaya untuk bersenang-senang. Tren kurangnya pemahaman dan minat orang 
untuk mengenal organisasi budaya, termasuk museum seni, memang menjadi persoalan di berbagai negara, termasuk di Indonesia. Jika survey dilaksanakan di Indonesia, memungkinkan jika hasil persentase yang didapat tak jauh dengan survey yang dilaksanakan oleh Culture Track di Amerika Serikat. Dalam era media sosial ini, museum dan karya seni merupakan bagian dari objek yang dianggap"Instagram-worthy". Bagi banyak orang, tampaknya fokus kunjungan museum telah bergeser dari melihat seni (tindakan keterlibatan intelektual dan emosional), menjadi untuk membuat orang lain tahu bahwa Anda sedang melihat seni. Kini, hampir setiap bulan kita bisa menemukan pameran seni dimana audiensnya didominasi oleh remaja. Pameran dalam museum ini biasanya mengusung seni modern, seni instalasi, atau pop up museum. Berbeda dengan dahulu kala dimana audiens museum didominasi oleh orang tua maupun wisatawan asing. Menurut The American Alliance of Museum, milenial merupakan generasi awal digital natives dan di era digital ini, mengunjungi museum dapat mendukung gaya hidup mereka.

Berdasarkan latar belakang permasalahan diketahui bahwa museum pada umumnya dikunjungi masyarakat sebagai tempat untuk mempelajari warisan peninggalan sejarah, seperti artefak, kerajinan bersejarah, pakaian bersejarah, dan sebagainya. Seiring perkembangannya, museum mulai berkembang menjadi art museum yaitu sebuah museum di mana orang-orang datang untuk menikmati perkembangan seni visual dari berbagai masa. Berbagai hal yang dapat ditemui di art museum contohnya seperti lukisan, karya pahat, instalasi, dan lain-lain.

Karya seni di art museum dulu dinikmati dengan mengetahui sejarah/ makna masing- masingnya, sekarang karya seni di art museum diperalat untuk membentuk personal branding di sosial media. Personal branding yang umumnya dilakukan dalam dunia nyata mulai diterapkan pula dalam dunia maya. Banyak orang berpose sedekat mungkin di depan karya, mencoba mengambil foto diri ataupun selfie bersama para pengunjung lain. Perilaku pengunjung museum yang hanya berfokus pada mengambil foto menimbulkan pro-kontra. Di satu sisi hal ini dapat meningkatkan publikasi dan ketertarikan masyarakat dalam mengunjungi museum. Namun, perilaku ini juga menimbulkan kerugian seperti rusaknya karya yang ditampilkan. Seperti ketika karya Yayoi Kusama ditampilkan di Museum MACAN dan ada beberapa karyanya yang dikabarkan mengalami kerusakan karena ulah pengunjung yang ceroboh dan terlalu berdekatan ketika sibuk mengambil foto.

\subsection{Rumusan Masalah}

Bagaimana proses pembentukan personal branding di media sosial pada mahasiswa pengunjung Museum MACAN?

\subsection{Signifikansi Penelitian}

Penelitian ini diharapkan dapat member signifikansi baik dari segi akademis, praktis, maupun sosial. Adapun signifikansi tersebut adalah sebagai berikut:

\section{Signifikansi Akademis}

a. Penelitian ini diharapkan dapat menjadi karya penelitian yang bermanfaat bagi penelitian dengan topik sejenis serta berhubungan dengan teori dan konsep yang terdapat dalam penelitian yang dilakukan.

\section{Signifikansi Praktis}

a. Penelitian ini diharapkan dapat menjadi rekomendasi untuk rujukan peneliti dan praktisi berikutnya yang ingin meneliti mengenai personal branding pada media sosial.

b. Bagi pengelola museum, menambah wawasan agar bisa terus memahami pola konsumsi para pengunjungnya mengenai 
kebiasaan dan perilaku mereka dalam mengunjungi museum.

c. Bagi pengembang aplikasi, menambah wawasan dalam memahami pola konsumsi para penggunanya mengenai kebiasaan dan perilaku mereka dalam menggunakan aplikasi.

\section{Signifikansi Sosial}

a. Penelitian ini diharapkan dapat memberikan sebuah refleksi atas pemaknaan baru terkait personal branding pada media sosial Instagram. Personal branding yang sebelumnya identik dengan dunia nyata kini dapat diterapkan pula pada dunia maya.

\section{Tinjauan Pustaka}

\subsection{Personal branding}

Definisi personal branding: "Personal branding is about taking control of how other people perceive you before they come into direct contact with you.". Terdapat tiga dimensi utama pembentuk personal branding:

\section{a. Kompetensi}

Kompetensi atau kemampuan individu untuk membangun reputasi atau personal branding, kita harus memiliki suatu kemampuan khusus atau kompetensi dalam satu bidang tertentu yang dikuasai. Seseorang dapat membentuk sebuah personal branding melalui sebuah polesan dan metode komunikasi yang disusun dengan baik. Personal Brand adalah sebuah gambaran mengenai apa yang masyarakat pikirkan tentang seseorang. Hal tersebut mencerminkan nilai-nilai, kepribadian, keahlian dan kualitas yang membuat seseorang berbeda dengan yang lainnya.

\section{b. Style}

Gaya merupakan kepribadian dari personal branding anda. Gaya merupakan bagian yang menjadikan diri anda unik di dalam benak orang lain. Gaya adalah cara anda berhubungan dengan orang lain.
Seringkali kata-kata yang digunakan orang untuk menilai gaya kita mengandung suatu emosi yang kuat,

\section{c. Standar}

Standar personal branding anda sangat mempengaruhi cara orang lain memandang diri anda. Standar akan menetapkan dan memberikan makna terhadap kekuatan personal branding. Namun kuncinya adalah anda sendiri yang menetapkan standar, anda sendiri yang harus melakukan. Terkadang kita menetapkan standar yang terlalu tinggi dan terlanjur mengatakan pada orang lain bahwa kita mampu melakukan suatu hal dengan cepat dan dapat memperoleh hasil yang baik (agar kompetensi dan gaya personal branding kita kelihatan menarik di benak semua orang). Namun yang terjadi adalah sebaliknya terkadang kita gagal untuk mencapai standar yang kita tetapkan sendiri.

Terdapat delapan konsep dalam personal branding (The Eight Laws of Personal branding) yang menjadi konsep utama yang menjadi acuan dalam membangun suatu personal branding:

\section{Spesialisasi (The Law of Specialization)} Ciri khas dari sebuah personal brand yang hebat adalah ketepatan pada sebuah spesialisasi, terkonsentrasi hanya pada sebuah kekuatan, keahlian atau pencapaian tertentu. Spesialisasi dapat dilakukan pada satu atau beberapa cara, yakni:

a. Ability - misalnya sebuah visi yang strategis dan prinsip-prinsip awal yang baik.

b. Behavior - misalnya keterampilan dalam memimpin, kedermawanan, atau kemampuan untuk mendengarkan.

c. Lifestyle - misalnya hidup dalam kapal (tidak di rumah seperti kebanyakan orang), melakukan perjalanan jauh dengan sepeda.

d.Mission - misalnya dengan melihat 
orang lain melebihi persepsi mereka sendiri.

e.Product - misalnya futurist yang menciptakan suatu tempat kerja yang menakjubkan.

f. Profession - niche within niche misalnya pelatih kepemimpinan yang juga seorang psychotherapist.

g. Service - misalnya konsultan yang bekerja sebagai seorang nonexecutive director.

2 Kepemimpinan (The Law of Leadership)

Masyarakat membutuhkan sosok pemimpin yang dapat memutuskan esuatu dalam suasana penuh ketidakpastian dan memberikan suatu arahan yang jelas untuk memenuhi kebutuhan mereka. Sebuah personal brand yang dilengkapi dengan kekuasaan dan kredibilitas sehingga mampu memposisikan seseorang sebagai pemimpin yang terbentuk dari kesempurnaan seseorang.

3 Kepribadian (The Law of Personality) Sebuah personal brand yang hebat harus didasarkan pada sosok kepribadian yang apa adanya, dan hadir dengan segala ketidaksempurnaannya. Konsep ini menghapuskan beberapa tekanan yang ada pada Konsep Kepemimpinan (The Law of Leadership), seseorang harus memiliki kepribadian yang baik, namun tidak harus menjadi sempurna.

\section{Perbedaan (The Law of Distinctiveness)} Sebuah personal brand yang efektif perlu ditampilkan dengan cara yang berbeda dengan yang lainnya. Banyak ahli pemasaran membangun suatu merek dengan konsep yang sama dengan kebanyakan merek yang ada di pasar, dengan tujuan untuk menghindari konflik. Namun hal ini justru merupakan suatu kesalahan karena merek-merek mereka akan tetap tidak dikenal diantara sekian banyak merek yang ada di pasar.
5 The Law of Visibility

Untuk menjadi sukses, sebuah personal brand harus dapat dilihat secara konsisten terus-menerus, sampai Personal Brand seseorang dikenal. Maka visibility lebih penting dari kemampuan (ability)-nya. Untuk menjadi visible, seseorang perlu mempromosikan dirinya, memasarkan dirinya, menggunakan setiap kesempatan yang ditemui dan memiliki beberapa keberuntungan.

\section{Kesatuan (The Law of Unity)}

Kehidupan pribadi seseorang dibalik personal brand harus sejalan dengan etika moral dan sikap yang telah ditentukan dari merek tersebut. Kehidupan pribadi selayaknya menjadi cermin dari sebuah citra yang ingin ditanamkan dalam Personal Brand.

7 Keteguhan (The Law of Persistence) Setiap personal brand membutuhkan waktu untuk tumbuh, dan selama proses tersebut berjalan, adalah penting untuk selalu memperhatikan setiap tahapan dan trend. Dapat pula dimodifikasikan dengan iklan atau public relation. Seseorang harus tetap teguh pada personal brand awal yang telah dibentuk, tanpa pernah ragu- ragu dan berniat merubahnya.

8 Nama baik (The Law of Goodwill) Sebuah personal brand akan memberikan hasil yang lebih baik dan bertahan lebih lama, jika seseorang di belakangnya dipersepsikan dengan cara yang positif. Seseorang tersebut harus diasosiasikan dengan sebuah nilai atau ide yang diakui secara umum positif dan bermanfaat.

\subsection{Media Sosial}

Media sosial adalah bentuk komunikasi elektronik (seperti website untuk jejaring sosial dan microblogging) dimana pengguna membangun komunitas online untuk berbagi informasi, ide, pesan-pesan 
personal dan konten lainnya (seperti video) (Merriam- Webster, 2013). Ron Jones mengemukakan bahwa, media sosial lebih dari sekedar percakapan dua arah, lebih dari broadcast satu arah seperti media tradisional, media sosial memiliki keunikan yaitu dengan adanya ide tetap terhubung dengan site, sumber dan orang-orang lainnya (Jones, 2009).

\subsubsection{Instagram}

Instagram berasal dari kata "insta seperti kamera polaroid yang dikenal dengan "foto instan" dan kata "gram" seperti kata "telegram" yang dimana cara telegram sendiri adalah untuk mengirim informasi dengan cepat. Instagram adalah sebuah aplikasi membagikan foto yang memungkinkan penggunanya untuk mengambil foto, memberikan filter digital dan membagikannya ke berbagai layanan jejaring sosial termasuk Instagram sendiri. Pada media sosial Instagram dapat mengunggah foto dengan menggunakan jaringan internet, sehingga informasi yang ingin disampaikan dapat diterima dengan cepat.

\subsection{Mahasiswa}

Mahasiswa adalah seseorang yang sedang dalam proses menimba ilmu ataupun belajar dan terdaftar sedang menjalani pendidikan pada salah satu bentuk perguruan tinggi yang terdiri dari akademik, politeknik, sekolah tinggi, institut dan universitas (Hartaji, 2012:5). Seorang mahasiswa dikategorikan pada tahap perkembangan yang usianya 18 sampai 25 tahun. Tahap ini dapat digolongkan pada masa remaja akhir sampai masa dewasa awal dan dilihat dari segi perkembangan, tugas perkembangan pada usia mahasiswa ini ialah pemantapan pendirian hidup (Yusuf, 2012: 27).

\subsection{Museum}

Museum menurut International Council of Museum (ICOM) merupakan lembaga nonprofit yang bersifat permanen untuk memberikan pelayanan terhadap masyarakat dan perkembangannya, yang terbuka untuk umum, yang memiliki tugas untuk mengumpulkan, meneliti, melestarikan, mengomunikasikan, serta memamerkan warisan dari sejarah manusia. Menurut Douglas A. Allan, museum adalah sebuah gedung yang di bagian dalamnya menyimpan sejumlah kumpulan benda yang digunakan untuk kesenangan dan peneliti studi. Di Indonesia sendiri, terdapat banyak museum yang beragam sesuai dengan fungsi dan lokasi mereka masingmasing. Museum mulai bermunculan di Indonesia untuk menceritakan sejarah negara dan menyimpan benda-benda penting yang bersejarah di Indonesia. Beberapa contoh museum sejarah di Indonesia adalah Museum Nasional, Museum Bahari, dan Museum Joang 45.

\subsubsection{Pengunjung Art Museum}

Kategori pengunjung museum di Indonesia dikategorikan oleh Direktorat Museum pada Pedoman Museum Indonesia (2010: 22-23), dimana pengunjung museum dikategorikan dan dikelompokkan berdasarkan intensitas dan intense kunjungannya. Berdasarkan intensitasnya, pengunjung dibagi menjadi:

a. Kelompok yang secara rutin berhubungan dengan museum; kolektor, seniman, desainer, ilmuwan, mahasiswa, dan pelajar.

b. Kelompok pengunjung yang baru mengunjungi museum.

Berdasarkan tujuan kunjungannya, pengunjung museum dibedakan menjadi:
a.Pengunjung pelaku studi.
b.Pengunjung tujuan tertentu.
c.Pengunjung pelaku rekreasi.

Menurut Director Museum MACAN, pengunjung museum MACAN sebanyak $70 \%$ didominasi oleh wanita berumur 18 sampai 29 tahun. Bagi banyak dari mereka, pengalaman itu adalah pertama kalinya menginjakkan kaki di museum. Menurut 
Visitor Service Officer Museum MACAN, museum sudah didatangi sekitar 40.000 pengunjung dengan kunjungan rata-rata per hari 1.000 hingga 1.200 orang pada awal museum dibuka pada November hingga Desember 2017.

\section{Metode Penelitian}

\subsection{Paradigma Penelitian}

Paradigma yang kami gunakan dalam penelitian ini adalah paradigma post positivisme. Paradigma post positivisme merupakan perkembangan dari paradigma positivis yang memprediksi pola umum dan bersifat objektif. Namun, pada paradigma post positivism peneliti tidak mengabaikan subyektifitas yang ditemukan dalam objek penelitian (Creswell, 2010). Pengetahuan yang diperoleh melalui paradigm ini didasarkan pada observasi dan pengujian yang sangat cermat terhadap realitas objektif fenomena sosial yang ada. Realitas objektif dalam hal ini berusaha melihat dan menyajikan kebenaran yang sesuai dengan persepsi individu yang berada dalam fenomena sosial.

\subsection{Pendekatan Penelitian}

Penelitian ini menggunakan pendekatan kualitatif. Menurut Denzin dan Lincoln dalam Handbook of Qualitative Research, penelitian kualitatif terdiri dari serangkaian interpretatif, praktik material yang membuat dunia menjadi terlihat. Praktik-praktik ini mengubah dunia menjadi serangkaian representasi termasuk catatan lapangan, wawancara, percakapan, foto, rekaman dan memo menjadi diri sendiri. Pada tingkat ini, penelitian kualitatif melibatkan pendekatan interpretif, naturalistik terhadap dunia. Ini berarti bahwa peneliti kualitatif berusaha memahami, atau menafsirkan, fenomena dalam arti makna yang dibawa orang kepada mereka. (2000:3). Cara orang belajar memahami dan menafsirkan realitas sosial mereka adalah salah satu motif utama penelitian kualitatif.

Dalam penelitian ini, peneliti berusaha memahami bagaimana proses pembentukan personal branding yang dilakukan oleh mahasiswa pengunjung museum MACAN melalui media sosial Instagram mereka, dan faktor apa saja yang mendorong mahasiswa membentuk personal branding tersebut.

\subsection{Strategi Penelitian}

Dalam penelitian ini, peneliti menggunakan metode interview pada responden dan observasi terhadap akun instagram responden.

\subsection{Sifat Penelitian}

Penelitian ini merupakan penelitian yang bersifat deskriptif. Dalam penelitian deskriptif, peneliti mencoba menampilkan data murni, membuat perbedaan, dan menyediakan konten yang mampu memperjelas data yang. Penelitian ini berusaha mendeskripsikan fenomena pembentukan personal branding oleh mahasiswa melalui media sosial Instagram dengan berlatarkan Museum MACAN.

\subsection{Metode Pengumpulan Data}

Metode pengumpulan data adalah cara yang digunakan peneliti untuk memperoleh, mengkategorikan, dan menganalisis data. Menurut Lofland dan Lofland (1984) sumber data utama dalam penelitian kualitatif adalah kata-kata dan tindakan (data primer) selebihnya adalah data tambahan, seperti dokumen dan lainnya (data sekunder).

\subsubsection{Data Primer}

Data primer dalam penelitian ini diperoleh melalui wawancara mendalam (in-depth interview). Lincoln dan Guba (1985), menjelaskan bahwa wawancara dengan melakukan wawancara peneliti dapat mengkonstruksi mengenai orang, kejadian, organisasi, perasaan, motivasi, tuntutan, kepedulian, dan lain-lain. Dan wawancara dapat memverifikasi, mengubah serta memperluas informasi yang diperoleh dari sumber lain. Wawancara ini diharapkan dapat membantu peneliti untuk memberi- 
kan jawaban yang lengkap mengenai bagaimana seseorang membentuk personal branding dengan cara mengung-gah foto di sosial media mereka. Dalam penelitian ini, wawancara dilakukan kepada beberapa mahasiswa pengunjung Museum MACAN yang telah mengunggah foto mereka di media sosial Instagram.

Pertanyaan yang akan diajukan dalam interview oleh peneliti kepada informan adalah dengan open-ended question, pertanyaan ini ditujukan agar peneliti mengetahui dengan tepat jawaban yang diberikan oleh informan, peneliti tidak membatasi pilihan jawaban yang diberikan dan informan dapat menjawab pertanyaan secara bebas. Jawaban yang diberikan oleh informan akan direkam oleh peneliti, sehingga peneliti dapat mendengarkan kembali jawaban yang diberikan oleh informan.

\subsubsection{Data Sekunder}

a. Observasi

Observasi merupakan proses pengumpulan data yang dilakukan peneliti dengan mengamati fenomena yang terjadi di lapangan. Dalam penelitian ini, peneliti melakukan observasi pada beberapa akun pengguna media sosial Instagram yang akan diwawancara. Observasi dilakukan untuk mengamati pengaturan susunan dan konsistensi tema foto yang diunggah oleh para pengguna mengupload foto mereka ketika mengunjungi Museum MACAN dalam akun pribadi Instagram mereka. Kedua orang tersebut terlihat peduli dengan feeds akun pribadi Instagram mereka.

\section{b. Literatur}

Peneliti juga melakukan proses pengumpulan data melalui studi literatur. Dalam penelitian ini, data tambahan yang diperoleh peneliti berasal dari berbagai sumber literatur, seperti buku dan karya ilmiah yang memiliki keterkaitan dengan topik penelitian.

\subsection{Metode Pemilihan Informan}

Dalam penelitian ini informan ditentukan dengan teknik purposive sampling. Teknik purposive sampling yaitu teknik menentukan sampel penelitian dengan beberapa pertimbangan tertentu yang bertujuan agar data yang diperoleh nantinya bisa lebih representatif. Dalam teknik ini peneliti dapat memperoleh informasi yang diinginkan sesuai dengan permasalahan penelitian, dibandingkan apabila peneliti mengambil sampel dengan metode sampling lainnya. Data-data yang diperoleh selanjutnya akan dikaitkan dengan teori mengenai personal branding untuk melakukan analisis hasil temuan dan pembahasan.

Untuk kebutuhan penelitian ini maka peneliti akan memilih 2 orang informan untuk diwawancarai dengan kriteria, informan merupakan mahasiswa dengan umur 18-25 tahun dan informan tersebut pernah

\subsection{Metode Analisis Data}

Penelitian ini dimulai ketika peneliti tertarik dengan terdapat banyaknya mahasiswa yang mengunggah fotonya di akun pribadi sosial media mereka, terutama Instagram, ketika mereka mengunjungi sebuah museum. Peneliti melihat adanya keterkaitan antara fenomena ini dengan teori Personal branding. Salah satu museum yang terkenal dan banyak sekali dikunjungi oleh para mahasiswa pada saat itu adalah Museum MACAN, yang pada saat itu sedang memamerkan karya Yayoi Kusama dengan tajuk "Life Is the Heart of the Rainbow".

Setelah melakukan pengamatan terhadap foto-foto yang diunggah pada akun pribadi Instagram beberapa orang mahasiswa, peneliti memilih dua orang mahasiswa yang telah memenuhi kriteria yang ditetapkan untuk diwawancarai. Dalam wawancara mendalam, peneliti akan 
mencoba mencari tahu bagaimana proses pembentukan personal branding yang dilakukan informan

\subsection{Keabsahan Data}

Pemeriksaan keabsahan data dilakukan untuk membuktikan apakah penelitian yang dilakukan oleh peneliti benar-benar penelitian ilmiah sekaligus untuk menguji data yang diperoleh. Berikut ini kualitas penelitian (goodness criteria) atau kepercayaan atas hasil penelitian. Pengujian validitas dan reliabilitas data pada penelitian kuantitatif memiliki standar yang baku untuk mengukur validitas dan reliabilitas data temuan melalui pengujian terhadap alat ukur yang digunakan untuk menemukan data temuan, sedangkan penelitian kualitatif belum memiliki standar yang baku tersebut. Adapun, menurut Guba dan Lincoln (1994), terdapat empat kriteria keabsahan data pada penelitian kualitatif:

\subsubsection{Derajat Kepercayaan / Kredibilitas (Credibility)}

Kriteria ini berfungsi dalam pelaksanaan proses pengambilan informasi dengan informan agar tingkat kepercayaan penemuan dapat tercapai oleh peneliti. Guba dan Lincoln (1989) mengemukakan bahwa tingkat kredibilitas yang tinggi dapat dicapai apabila informan yang terlibat dalam penelitian kualitatif dapat mengenali benar tentang berbagai hal yang telah disampaikan kepada peneliti. Hal tersebut merupakan hal utama dalam menentukan kredibilitas penelitian.

\subsubsection{Keteralihan (Transferability)}

Transfer abilitas atau keteralihan merupakan kriteria yang menilai sejauh mana suatu temuan pada sebuah penelitian yang dilakukan oleh suatu kelompok tertentu dapat diaplikasikan pada kelompok lainnya. Peneliti tidak dapat dilihat secara langsung oleh peneliti, melainkan oleh pembaca peneliti tersebut. Apabila pembaca dapat mengerti hasil penelitian, memiliki gambaran dan pemahaman yang jelas tentang laporan penelitian, maka dapat dikatakan penelitian memiliki tingkat transfer abilitas yang tinggi.

\subsubsection{Kebergantungan (Dependability)}

Kriteria ini melihat sejauh mana sebuah temuan pada penelitian kualitatif menunjukkan adanya sebuah konsistensi pada hasil temuan ketika penelitian tersebut dilakukan oleh peneliti yang berbeda dan pada waktu yang berbeda.Tingkat dependabilitas suatu penelitian pada penelitian kualitatif dapat dilihat dengan melakukan analisis data yang terstruktur dan berupaya untuk menginterpretasikan hasil penelitian yang baik sehingga peneliti selanjutnya dapat menuliskan kesimpulan yang sama.

\subsubsection{Kepastian (Confirmability)}

Confirmability mencakup kepada tingkatan dimana hasil penelitian dapat dikonfirmasi oleh penelitian lain. Untuk mengokohkan objektivitas di dalam penelitian ini, peneliti sebaiknya menyajikan konsep yang lengkap dalam kerangka pemikiran, termasuk menyajikan penelitian yang lalu berkaitan dengan tema sejenis. Menguji confirmability berarti menguji hasil penelitian berkaitan dengan proses yang dijalankan, yang berarti bahwa penelitian akan memenuhi standar confirmability jika hasil penelitian merupakan fungsi dari proses penelitian yang telah dijalankan.

\subsection{Keterbatasan dan Kelemahan Peneli- tian}

Dalam proses penelitian ini, peneliti mengakui adanya keterbatasan dan kelemahan yang dialami peneliti, yakni terbatasnya waktu peneliti untuk mencari dan mewawancarai informan, peneliti hanya melakukan satu kali wawancara tatap muka dengan informan, dan akan kemudian dilanjutkan dengan menghubungkan informan secara online, melalui media sosial seperti WhatsApp atau Line jika terdapat informasi yang masih kurang jelas menurut peneliti. 


\section{Hasil dan Diskusi}

\subsection{Temuan Penelitian}

a. Kedua informan tidak terlalu memikirkan likes ketika mengunggah sesuatu di Instagram melainkan lebih mementingkan manfaat dari konten yang dibuat seperti, bermanfaat, positif dan juga menghibur.

b. Kedua informan sama-sama dipengaruhi oleh akun yang mereka follow di Instagram mereka tetapi informan pertama lebih mengikuti akun-akun official sedangkan informan kedua mengikuti akun selebgram yang difollow.

c. Kedua informan mengedit dahulu foto yang ingin mereka unggah, dan mereka juga memilih terlebih dahulu foto mana yang dianggap sesuai dengan feeds-nya.

d. Salah satu informan tidak terlalu memikirkan terlebih dahulu dimana tempat yang akan dijadikan background untuk berfoto, tetapi informan kedua memikirkan hal tersebut tetapi pada akhirnya mereka akan memilih foto yang sesuai dengan dirinya dan sesuai dengan feeds Instagramnya agar enak dilihat oleh orang lain.

e. Kedua informan ingin menunjukan persona sesuai dengan kesukaan dan kepribadian masing-masing.

f. Kedua informan tidak memiliki ketertarikan khusus pada seni.

g. Alasan kedua informan mengunjungi Museum MACAN adalah untuk berfoto-foto, dan hal ini memang sudah direncanakan.

h. Kedua informan hanya memperhatikan beberapa filosofi dari beberapa instalasi yang dianggapnya menarik.

i. Menurut informan pertama juga, terdapat lebih banyak perempuan yang berfoto-foto di dalam Museum MACAN, mayoritas laki-laki hanya menemani yang perempuan saja.

j. Kedua informan tidak pergi sendiri melainkan karena ada ajakan dari temannya. k. Kedua informan sama-sama mengunjungi Museum MACAN sebagai tempat yang sedang menjadi tren atau sedang didatangi di Instagram.

1. Kedua informan merasa seharusnya dress up ketika mengunjungi Museum MACAN, sehingga informan satu merasa malu dan tidak ingin mengunggah di Instagram foto yang menampakkan pakaian yang dikenakan sementara informan kedua janjian dengan teman-temannya untuk menggunakan outfit berwarna putih.

\subsection{Data Penelitian}

Data penelitian menunjukan bahwa Naura dan Angel menggunakan Instagram untuk membuat konten yang mereka sukai, dan kedua informan suka menunjukan konten yang menunjukan keahliannya di bidang masing-masing, seperti misalnya naura suka mengunggah atau menunjukan konten yang berhubungan dengan liputan berita sesuai dengan peminatannya di perkuliahan yaitu jurnalisme, sedangkan Angel suka mengunggah konten yang menunjukan halhal mengenai prestasinya secara konsisten sebagai mahasiswa kajian media.

Dalam mengunggah foto di Instagram Kedua informan tidak terlalu memikirkan likes ketika mengunggah sesuatu di Instagram melainkan lebih mementingkan manfaat dari konten yang dibuat seperti, bermanfaat, positif dan juga menghibur. Kemudian kedua informan sama-sama dipengaruhi oleh akun yang mereka follow di Instagram mereka tetapi informan pertama lebih mengikuti akun-akun official berita atau life style sedangkan informan kedua mengikuti akun selebgram yang difollow. Naura tidak terlalu memikirkan terlebih dahulu dimana tempat yang akan dijadikan background untuk berfoto, sedangkan Angel memikirkan hal tersebut tetapi pada akhirnya mereka akan memilih foto yang sesuai dengan dirinya dan sesuai dengan feeds Instagramnya agar enak dilihat oleh orang lain. Mereka masingmasing juga selalu mengedit terlebih dahulu foto yang akan mereka unggah. 
Kedua informan ingin menunjukan persona sesuai dengan kesukaan dan kepribadian masing-masing. Mereka tidak ingin menunjukan sesuatu yang dibuatbuat. Seperti Naura ingin menunjukan dirinya yang fun, suka tertawa sesuai dengan kepribadiannya di dunia nyata. Sedangkan Angel ingin menunjukan dirinya sebagai anak muda, mahasiswi yang berprestasi di bidang yang diminatinya yaitu kajian media.

Berdasarkan data kedua informan samasama tidak mempunyai ketertarikan terhadap seni. Alasan kedua informan mengunjungi Museum MACAN adalah untuk berfoto-foto, dan hal ini memang sudah direncanakan, karena pada saat itu museum MACAN merupakan salah satu tempat yang sedang menjadi tren atau sedang trend di Instagram dan kedua informan pergi ke Museum MACAN karena ajakan temannya. Kedua informan juga tidak terlalu memperhatikan filosofi dan instalasi yang dipamerkan di Museum MACAN, mereka hanya memperhatikan beberapa filosofi dari beberapa instalasi yang mereka anggapnya menarik. Karena tujuan awalnya mereka datang ke Museum MACAN hanya untuk berfoto-foto. Menurut informasi dari informan pertama, terdapat lebih banyak perempuan yang berfoto-foto di dalam Museum MACAN, mayoritas laki-laki hanya menemani yang perempuan saja, mereka berpakaian rapi dan membawa alat untuk berfoto. Kedua informan merasa seharusnya dress up ketika mengunjungi Museum MACAN, sehingg informan satu merasa malu dan tidak ingin mengunggah di Instagram foto yang menampakkan pakaian yang dikenakan sementara informan kedua janjian dengan teman-temannya untuk menggunakan outfit berwarna putih.

\subsection{Diskusi Data Penelitian}

Instagram sebagai salah satu media yang memiliki kemampuan untuk mengirim informasi secara cepat melalui foto, digunakan oleh kedua informan dalam membentuk personal branding mereka. Melalui Instagram, setiap orang dapat memberikan likes dan comment kepada unggahan orang lain sehingga setiap penggunanya dapat mengetahui bagaimana penilaian orang lain terhadap unggahannya. Hal ini juga dialami oleh kedua informan, khususnya informan kedua yang memang memperhatikan penilaian dari orang lain terhadap dirinya sehingga Instagram memiliki peran penting bagi informan kedua untuk mengetahui bagaimana penilaian orang terhadap perkembangan dirinya. Sementara itu, informan pertama lebih memanfaatkan Instagram sebagai tempat mengekspresikan hal-hal yang sedang terjadi dalam kesehariannya. Kedua informan memiliki usia yang sama, 21 tahun, memiliki profesi yang sama yakni mahasiswa. Mahasiswa dapat digolongkan pada fase remaja akhir sampai dewasa awal yang biasanya merupakan tahap pemantapan pendirian hidup. Dalam konteks ini, kedua informan merupakan remaja, dimana pada umumnya remaja memiliki ketertarikan untuk mengikuti halhal yang sedang menjadi tren di lingkungannya.

Terdapat beberapa perbedaan yang signifikan di antara kedua informan yang juga berpengaruh pada output dari unggahan mereka di Instagram masingmasing. Perbedaan pertama terlihat dari informan pertama tidak begitu mementingkan followers atau pengikutnya di Instagram sehingga foto yang diunggah tidak terlalu mempertimbangkan penilaian pengikutnya, sedangkan informan kedua cukup mementingkan jumlah pengikutnya dan jumlah likes sehingga ia merasa penting untuk menjaga citra atau image-nya di Instagram miliknya agar tidak memberikan dampak kepada pengikutnya. Hal ini dapat dikaitkan dengan konsep personal branding pada bagian The Law of Unity, dimana kehidupan pribadi seseorang harus sesuai dengan etika moral dan sikap 
yang telah ditentukan oleh individu tersebut. Kehidupan asli individu selayaknya menjadi cerminan dalam membentuk personal branding sehingga apa yang ditunjukkan oleh individu sejalan dengan kehidupan aslinya.

Pengikut informan pertama di Instagram juga lebih rendah dari informan kedua, dimana informan pertama memiliki 760 followers dan informan kedua memiliki 1,707 followers. Kedua informan memiliki jumlah unggahan di Instagram yang jauh berbeda. Informan pertama cukup sering mengunggah foto secara berkala, sedangkan informan kedua cukup jarang mengunggah foto di Instagramnya. Dari perspektif personal branding, informan pertama cenderung lebih menunjukkan kehidupan sosialnya secara up to date, sedangkan informan kedua cenderung lebih menitikberatkan pada prestasinya yang diraih pada bidang akademis dan tidak mengunggah kesehariannya secara berkala. Namun, kedua informan ini memiliki tema unggahan yang konsisten sesuai dengan minatnya. Hal ini dapat berpengaruh pada jumlah pengikut kedua informan, informan pertama menarik lebih sedikit pengikut, sementara informan kedua menarik lebih banyak jumlah pengikut. Hal ini dapat disebabkan oleh konten informan kedua yang didominasi dengan prestasi yang menonjol sehingga mendorong orang untuk mengikutinya. Hal ini sesuai dengan konsep personal branding pada bagian The Law of Distinctiveness, di mana individu menampilkan personal branding-nya dengan cara yang berbeda dari personal branding yang umumnya dibentuk oleh individu lainnya sebagai pembeda dari individu yang lain. Sementara itu, informan pertama memiliki lebih sedikit pengikut karena konten yang diunggah sama seperti kebanyakan pengguna Instagram seusianya, di mana hal tersebut bukan merupakan wujud dari personal branding yang sesuai dengan The Law of Distinctiveness.
Jika dilihat dari akun-akun yang diikuti kedua informan, informan pertama cenderung tidak mengikuti akun-akun influencer, namun cenderung mengikuti akun-akun berita yang sesuai dengan minatnya di bidang jurnalistik (sesuai dengan peminatannya di kuliah). Informan kedua cenderung mengikuti akun-akun influencer yang memiliki prestasi di bidang akademis, seperti MaudyAyunda, dimana hal ini sejalan dengan tema unggahan pada akun Instagramnya. Kedua hal ini sejalan dengan konsep The Eight Laws of Personal branding, khususnya pada komponen The Law of Specialization. Komponen ini menjelaskan bahwa personal branding yang baik harus sesuai dengan spesialisasi yang dimiliki oleh individu, terkonsentrasi pada sebuah kekuatan, keahlian, atau pencapain tertentu. Kedua informan telah membentuk personal branding sesuai dengan konsep ini, di mana unggahan mereka difokuskan sesuai dengan keahlian masing-masing. Informan pertama menunjukan keahliannya pada bidang jurnalistik serta gaya hidup yang sejalan dengan beberapa cara dari konsep The Law of Specialization yakni Profession (niche within niche) dan Lifestyle. Sementara itu, informan kedua menunjukan keahliannya pada bidang akademik sebagai mahasiswa kajian media. Hal ini sejalan dengan konsep The Law of Specialization, tepatnya Ability.

Dalam persiapan kedua informan pada saat pengambilan foto untuk diunggah ke Instagram, informan pertama tidak terlalu mempersiapkan penampilannya, hal tersebut sejalan dengan personal branding yang tidak mementingkan penilaian orang lain di Instagram. Informan kedua cenderung lebih melakukan persiapan penampilan sebelum mengambil foto untuk diunggah, hal ini juga sejalan dengan personal branding yang ia bentuk untuk menjaga citra dirinya di Instagram.

Informan pertama juga cenderung tidak mempersiapkan atau memikirkan terlebih dahulu terkait latar foto untuk diunggah, 
sedangkan informan kedua sudah mengetahui dan merencanakan tempat foto yang akan diunggah. Hal tersebut sejalan dengan personal branding kedua informan di mana informan pertama cenderung lebih menunjukkan dirinya yang apa adanya dan spontan. Hal ini sejalan dengan konsep personal branding pada bagian The Law of Personality, di mana sebuah personal brand yang baik harus berlandaskan pada sosok kepribadian yang apa adanya, dan hadir dengan segala ketidaksempurnaannya.

Informan kedua lebih mempertimbangkan konten yang akan diunggah, dimana ia merupakan individu yang sangat peduli dengan tanggapan orang lain sehingga ia lebih mempersiapkan dan memikirkan latar foto yang akan diunggah. Hal ini sejalan dengan konsep personal branding pada bagian The Law of Goodwill di mana informan kedua berusaha membentuk unggahannya agar dapat mendapatkan penilaian atau persepsi yang positif dari para followers.

Kedua informan sebenarnya tidak memiliki ketertarikan dalam bidang seni, namun mereka datang dan mengunggah foto di Museum MACAN adalah karena tingginya tingkat popularitas tempat tersebut pada saatitu. Kedua informan mengunjungi dan mengunggah foto-foto yang telah diambil dari tempat tersebut untuk menunjukkan kepada para followers bahwa mereka mengikuti tren dan perkembangan zaman.

\section{Kesimpulan}

Personal branding kini tidak hanya dilakukan di kehidupan nyata, dengan perkembangan pesatdari media sosial, personal branding lebih cenderung dilakukan melalui media sosial seperti Instagram. Peneliti memilih dua orang mahasiswa yang telah membentuk personal branding dengan mengunggah foto mereka di Museum MACAN. Berdasarkan penelitian, terdapat dua pola berbeda yang ditemukan dalam pembentukan personal branding oleh mahasiswa. Pola ini dibedakan oleh ciri-ciri yang mengacu kepada konsep-konsep di dalam The Eight Laws of Personal branding. Di dalam pola pertama, terdapat konsistensi dalam menjaga citra diri yang ditampilkan. Pola pertama membangun personal branding sebagai juara di bidang akademis. Pola ini didukung konten yang disaring sedemikian rupa sehingga antara bagaimana seseorang ingin dipersepsikan dan apa yang ditampilkan berjalan seiringan. Nilai-nilai dasar dalam pola pertama termasuk cerdas, beretika baik, dan berdampak positif terhadap publik. Nilainilai yang terbungkus dalam konten Instagram ini berhasil membedakannya dari pola kedua dan lebih menarik minat mahasiswa, terbukti dalam pola pertama terdapat jumlah followers yang lebih signifikan. Konsistensi dalam membangun personal branding yang mengacu kepada The Eight Laws of Personal branding membuktikan bahwa penanda yang berbeda dari yang lain merupakan kunci dari personal branding.

Sementara itu, pola kedua cenderung menampilkan pribadi yang apa adanya, sebagaimana dirinya di dunia nyata. Pola kedua membangun personal branding sebagai mahasiswa yang fun dan care free, terlihat dari konsistensinya dalam mengunggah konten yang lebih menunjukan aktivitas dan gaya hidup yang dijalani setiap hari. Jika dilihat dari konsep di dalam The Eight Laws of Personal branding, nilai-nilai yang ada dalam pola kedua adalah fun, aktif beraktivitas, tidak peduli pendapat orang lain, berkepribadian apa adanya dan tidak terlalu peduli penampilan. Nilai-nilai yang ditunjukan pada konten Instagram pada pola kedua merupakan nilai-nilai yang sebenarnya biasa ditampilkan oleh mahasiswa pada umumnya, sehingga pola ini tidak standout dan tidak terlalu menarik perhatian. Hal ini dapat kita lihat dari jumlah followers yang kurang signifikan, tetapi hal ini tidak 
kominfo terus lakukan percepatan pembangunan broadband. Diakses dari https://kominfo.go.id/content /detail/12640/siaran-pers-no53hmko minfo/022018-tentang-jumlah-peng guna-internet-2017-meningkat-kom info-terus-lakukan-percepatan-pem bangunan-broadband/0/siaran_ pers

Munthe, J., et.al. (2018). Museum bertahan dari gerusan zaman. Diakses 27 Maret 2019 dari https://www. validnews.id/Museum-Bertahan-dari -Gerusan-Zaman-NUZ

\section{Daftar Pustaka}

Creswell, J. W. (2010). Research design pendekatan kualitatif, kuantitatif, dan mixed Ed. 3. Yogyakarta: Pustaka Pelajar.

Direktorat Museum. (2010). Pedoman museum Indonesia. Jakarta: Direktorat Jenderal Sejarah dan Purbakala Kementrian Kebudayaan dan Pariwisata.

Gunarsa, S., \& Yulia (2006). Psikologi perkembangan anak dan remaja. Jakarta: PT Gunung Mulia.

Hasibuan, R. (2017). Museum Macan dan tantangan era selfie. Diakses pada 27 maret 2019 dari https://crafters.get craft.com/id/museum-macanindonesia

Jones, R. (2009). Social media marketing 101, Part 1. Search Engine Watch. 29 Februari 2009.

Kaplan, I. (2017). 37\% of art museum visitors don't view them as cultureand other takeaways from the 2017 culture track report. diakses 27 maret 2019 dari https://www.artsy.net/ article/artsy-editorial-37-art-museum -visitors-view-culture-takeaways2017-culture-track- report

Kementerian Kominfo. (2018). Jumlah pengguna internet 2017 meningkat,
Social Media (2019). In MerriamWebster.com 2013. Diakses Maret 27, 2019 dari https://www.merriamwebster.com/dictionary/social\%20 media

Sulistyowati, D. (2016). Kajian pengunjung museum: upaya menarik pengunjung potensial ke museum. Diakses 27 Maret 2019 dari https://museumku.wordpress.com/20 16/ 03/18/kajian-pengunjung-muse um-upaya-menarik-pengunjung-pote nsial- ke-museum/

Wreksono, A. (2018). Art 'damaged' at interactive exhibit at Museum Macan. Diakses 27 Maret 2019 dari https:// www.thejakartapost.com/ life/2018/05/1 9/art-damaged-atinteractive-exhibit-at-museummacan.html 